\title{
First report of a surf zone diatom accumulation in the Eastern South Pacific: Aulacodiscus kittonii Arnott ex Ralfs (Bacillariophyta) as the dominant and exclusive species
}

\section{Primera cita de una acumulación de diatomeas de la zona de rompiente de las olas en el Pacífico Sur Oriental: Aulacodiscus kittonii Arnott ex Ralfs (Bacillariophyta) como la especie dominante y exclusiva}

\author{
Patricio Rivera ${ }^{1 *}$, Fabiola Cruces ${ }^{1} \&$ Víctor A. Gallardo ${ }^{2}$ \\ ${ }^{1}$ Department of Botany, University of Concepcion, P.O. Box 160-C, Concepcion, Chile. \\ ${ }^{2}$ Department of Oceanography, University of Concepcion, P.O. Box 160-C, Concepcion, Chile. \\ *privera@udec.cl
}

\begin{abstract}
The so-called "surf diatoms" constitute a small group of species that are present with great abundance in the surf zones of some sandy beaches where often the accumulations are dominated only for one of these species. They adhere to air bubbles generated by wave action forming green or brown patches that float in the surf zone, remaining as long streaks on the beach. In May 2015 a green accumulation was detected in Coquimbo Bay in northern Chile. The study of samples with light and electron microscopy techniques showed the presence of Aulacodiscus kittonii, a well-known surf diatom. This is the first report of this kind for Chile and for the whole coast of the Eastern South Pacific Ocean with A. kittonii as the dominant species. It is also the first report for Chile as a living taxon. A description of the Chilean specimens is given with comments and photographs on the variation of some of its morphological features.
\end{abstract}

KEYwORDS: Surf diatoms, sandy beaches, diatom bloom, morphology, Chile.

\section{RESUMEN}

Las diatomeas de la zona de rompiente de las olas constituyen un grupo reducido de especies que producen acumulaciones masivas sobre playas arenosas con fuerte oleaje, a menudo como únicas dominantes de la comunidad. Se unen a las burbujas generadas por el oleaje y forman masas flotantes de color marrón o verde, de forma irregular, las que luego con la marea se depositan sobre la playa formando franjas largas. En mayo de 2015 una de estas acumulaciones, de color verde, fue detectada en la Bahía de Coquimbo. El análisis de las muestras mediante microscopía óptica y electrónica de barrido demostró la presencia de la diatomea Aulacodiscus kittonii, un taxón muy conocido por participar en este tipo de eventos. Este es el primer registro para Chile y para el Pacífico Sur Oriental, evento en el cual $A$. kittonii fue la especie dominante, como también el primer registro para Chile de A. kittonii como una especie viviente. Se entrega una descripción de los especímenes chilenos y se comenta e ilustra la variabilidad de algunas de sus características morfológicas.

Palabras clave: Diatomea de rompiente, playas arenosas, proliferación de diatomeas, morfología, Chile.

\section{INTRODUCTION}

"Surf diatoms" constitute a small group of species that accumulate in great abundance in the surf zones of some sandy beaches with high wave energy (Campbell 1996). They accumulate in the foam by adhering to air bubbles generated by wave action (Odebrecht et al. 2014), forming green or brown irregular patches floating in the surf zone, causing deep coloration of the water and remaining as long streaks on the beach (Lewin 1973). After some hours the cells lose buoyancy and the accumulations tend to disappear (Du Preez \& Campbell 1996). The populations are dominated only by one or two unrelated species, centric or pennate diatoms, single cells to colonies, but several species can be present as sub-dominant (Campbell 1996). According to Campbell (1996) and Odebrecht et al. (2014) there are only seven 
confirmed surf diatom species: Anaulus australis Drebes et Schulz, Attheya armata (West) Crawford, Asterionellopsis glacialis s.l. (see Kaczmarska et al. 2014), Aulacodiscus kittonii Arnott ex Ralfs, Aulacodiscus africanus Cottam, Aulacodiscus johnsonii Arnott in Pritchard and Aulacodiscus petersii Ehrenberg, the last two taxa as subdominants in South Africa (Campbell, 1996). According to Talbot \& Bate (1990) surf diatom accumulations have occurred in the Southern Hemisphere between the latitudes $29^{\circ}$ to $34^{\circ} \mathrm{S}$, but more recently Odebrecht et al. (2014) extended the area between $42^{\circ} \mathrm{N}$ and $42^{\circ} \mathrm{S}$, emphasizing that most of the localities are located in the southern Hemisphere. However, at that time, they were completely unknown for the Eastern South Pacific.

This work aims to report for the first time for Chile a surf diatom accumulation that recently occurred in the northern coast of the country, investigate its species composition using light and electron microscopy, contributing information on the variability of some characteristics of the frustule of the dominant species.

\section{MATERIAL AND METHODS}

The samples were collected on May 28, 2015 in Coquimbo Bay (Enjoy Beach), centered approximately at $29^{\circ} 53^{\prime} \mathrm{S}-71^{\circ} 17^{\prime} \mathrm{W}$, within the Coquimbo Region of Chile (Fig. 1). The bay extends between Tortuga Point in the south and Teatinos Point in the north and it is affected by the prevailing south-west winds producing strong waves (Tabilo et al. 1990). However, winds from the north are frequent throughout the year (Olivares 1989). The bay opens to the west and has a sandy beach of $18 \mathrm{~km}$ in length. The bathymetry shows a mean depth of $25 \mathrm{~m}$ and a maximum depth of $50 \mathrm{~m}$. The bathymetry changes abruptly around the Points but slopes gently elsewhere. It receives the influence of several freshwater streams, domestic wastes from La Serena city, and before the construction of Puclaro Reservoir (2000), the discharges of the Elqui River had an important influence on this bay (Soto et al. 2015). Actually, they have not any influence (Soto et al. 2015). The Elqui River provided a large proportion of fine sediments to the Bay, especially in the austral spring and summer months caused by snow-melt from the Andes mountain range (Valle-Levison et al. 2000). Precipitation in the area occurs mainly during winter months and increase noticeably during El Niño events (Soto et al. 2015).

We have no information about the physical, chemical and biological factors present when the material was obtained. The collections were done during a rather warm, sunny and calm day, and during the three previous days the predominant winds were from the $\mathrm{E}$ and SE, with intensities between 5.5 and $11.1 \mathrm{~km} / \mathrm{h}$ (Dirección Meteorológica de Chile 2016). Collections were made at Enjoy Beach directly from the surf zone and from the material accumulated along the beach (Fig. 2. A-C). Samples were preserved with formaldehyde (4\%) and were deposited at the Diatom Collection, Department of Botany, University of Concepcion, Chile with the numbers DIAT-CONC M-3471, 3472, and as permanent slides (Hyrax) with de numbers DIAT-CONC 7666, 7667 and 7668. A fraction of the samples was treated for the removal of organic matter according to the method described by Hasle \& Fryxell (1970). More than 2000 cells were analyzed by means of light microscopy (LM) using a Zeiss Photomicroscope III and a Olympus CT-31, and by Scanning Electron Microscopy (SEM) using a JEOL JSM-6380 LVY. Critical point drying, as described by Anderson (1951) was used to observe the cingulum and velum structure. Terminology used is that suggested by Anonymous (1975), Ross et al. (1979) and Holmes \& Mahood (1980).

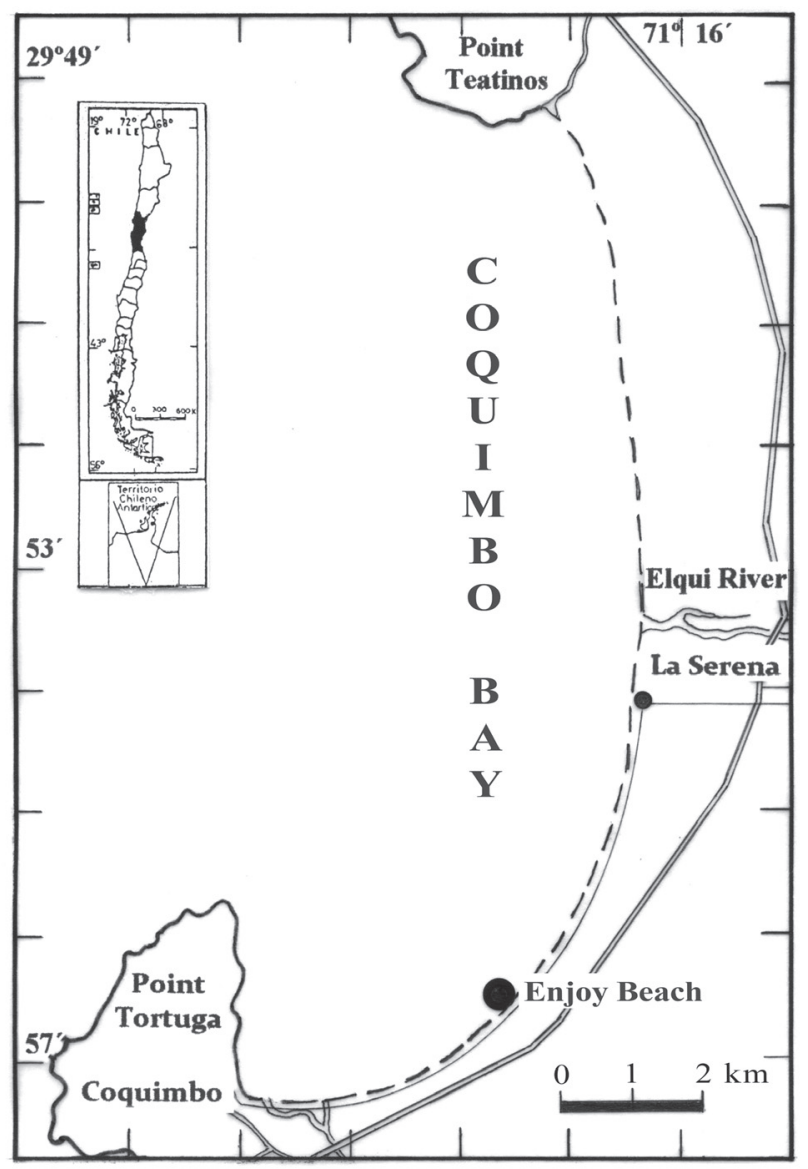

FIgURE 1. Upper left, map of Chile characterizing the Region of Coquimbo. Right, map of Coquimbo Bay and location of Enjoy Beach.

FIgURA 1. Arriba izquierda, mapa de Chile caracterizando a la Región de Coquimbo. Derecha, mapa de la Bahía de Coquimbo y ubicación de la Playa Enjoy. 


\section{RESULTS}

The water of Coquimbo Bay had a deep green color when the samples were collected from irregular patches being stranded by the gentle wave action forming extensive deposits on the beach as tide receded (Fig. 2. A-C).

The analysis with light and scanning electron microscopy of the material collected, showed the exclusive presence of Aulacodiscus kittonii Arnott ex Ralfs, a well-known surf diatom species. No other genera or species of diatoms, or representatives from other groups of microalgae were present.

The cells of A. kittonii are solitary, circular in outline with diameters ranging from 66 to $170 \mu \mathrm{m}$, truncated oblong in girdle view with the submarginal processes protruding (Fig. 3. A). The green-brown chloroplasts are discoid, numerous and large, 5.5-9.0 $\mu \mathrm{m}$ in diameter (Fig. 2. D). The valves present a flat central surface, rising at the submarginal processes and concave between them (Fig. 3 . F-J). The labiate processes are normally four (Fig. 3. B, F-G), occasionally five (Fig. 3. I-J; Fig. 4. F), and rarely six (Fig. 3. C, H; see comment in Discussion, third paragraph), expanded into large hyaline hood-like structures (Fig. 3. A). Valves are strongly areolated, arranged in radial rows (Fig.
3. I, K). The loculate areolae are hexagonal, but those on the central area are angular and larger; some areolae located at the hyaline rays are pentagonal (Fig. 3. K). Areolae number five in $10 \mu \mathrm{m}$ at the center, being barely denser towards the margin, six to seven in $10 \mu \mathrm{m}$. A central rosette (5.7-9.0 $\mu \mathrm{m}$ in diameter), without a hyaline area, is present in all observed external valves (Fig. 3. I, K). The outer velum of each areola has pores arranged in more or less parallel lines and lacks a raised central papilla (Fig. 3. L-M). However, two to seven small papillae are present on the external marginal walls of each areola (Fig. 3. M). The foramina are internal, large (Fig. 4. C, D) with an eccentric location in the central areolae, and in those areolae bordering the hyaline rays, lying in the internal side of the valves between the center and the processes (Fig. 3. K). The external surface of each labiate process consists of a domed hood with three slits suggesting a trident (Fig. 4. B). Internally, and attached to the top of each submarginal valve cavity, appears a raised double horse-shoe-shaped structure of the labiate process (Fig. 4. C). Each cingulum is composed of five to six nonperforated open bands with a long ligula (Fig. 4. A). The valvocopula is $5.0-6.4 \mu \mathrm{m}$ wide, the width decreasing slightly in the abvalvar direction.
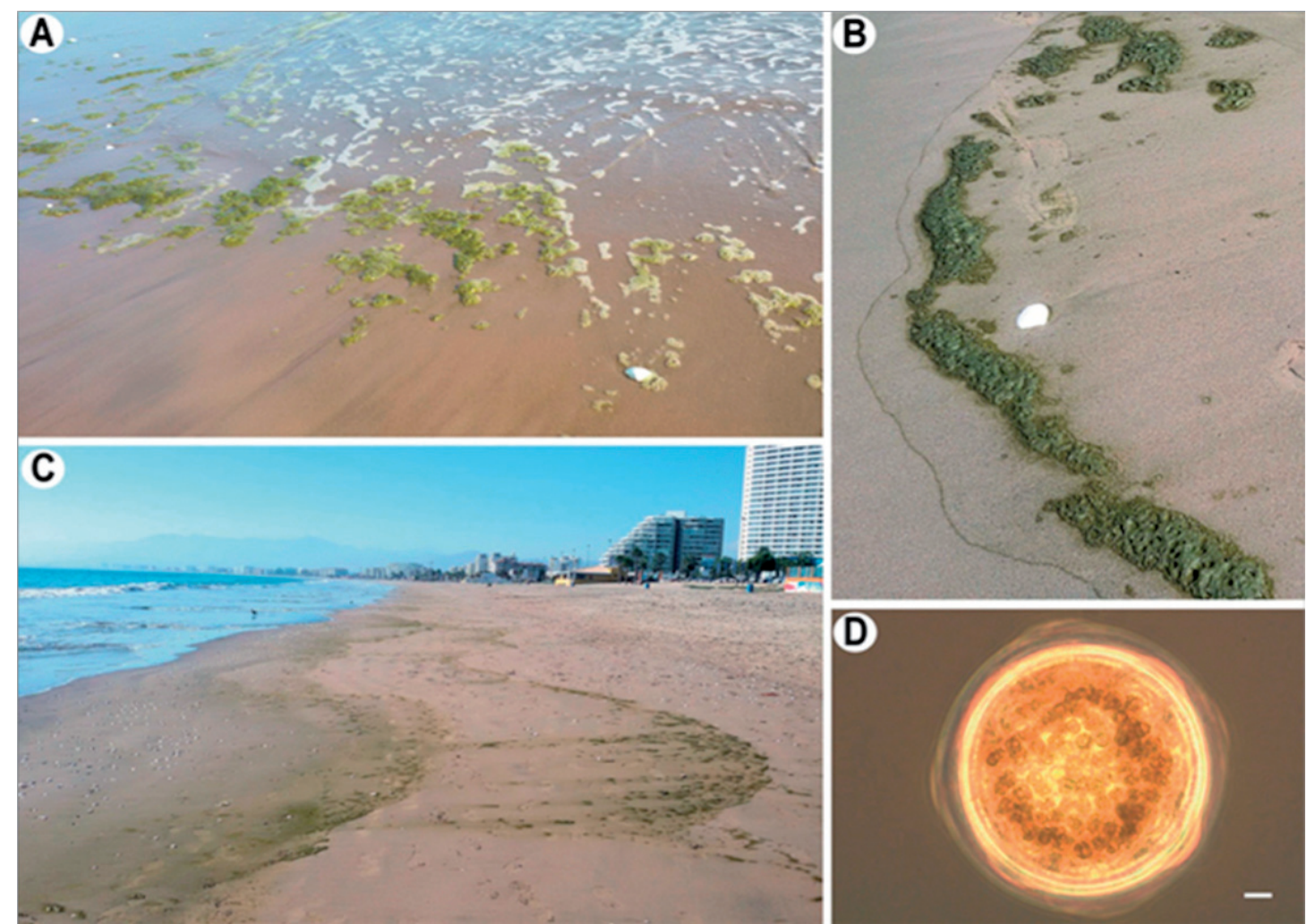

FiguRE 2. A. Green irregular patches of $A$. kittonii floating in the surface water of Coquimbo Bay. B-C. Deposits of $A$. kittonii masses on the Enjoy Beach. D. Cell of $A$. kittonii with numerous plastids. Scale $=10 \mu \mathrm{m}$. (Photos A-C by V.A. Gallardo).

Figura 2. A. Aglomerados verdes de A. kittonii de forma irregular flotando en la superficie del agua de la Bahía de Coquimbo. B-C. Depósitos de aglomerados de $A$. kittonii sobre la Playa Enjoy. D. Célula de A. kittonii con numerosos plastidios. Escala $=10 \mu \mathrm{m}$. (Fotos A-C de V.A. Gallardo). 



Figure 3. Aulacodiscus kittonii. A, F-M, Scanning Electron Microscopy; B-E, Light Microscopy. A. Frustule in conectival view. B-E. Valves with four, six, eight and ten labiate processes respectively. F-G. External and internal views of valves with four labiate processes. H. Internal view of valve with six labiate processes. I-J. External and internal views of valves with five labiate processes. K. External view of areolae in radial rows and lacking velum. Central rosette with angular areolae. Submarginal labiate process. L. External velum of areolae. M. Papillae on the marginal walls of each areola. Scale bars: A, F-J $=20 \mu \mathrm{m} ; \mathrm{B}-\mathrm{E}=40 \mu \mathrm{m} ; \mathrm{K}=10 \mu \mathrm{m} ; \mathrm{L}=5 \mu \mathrm{m} ; \mathrm{M}=1 \mu \mathrm{m}$.

Figura 3. Aulacodiscus kittonii. A, F-M, Microscopía Electrónica de Barrido; B-E, Microscopía Fotónica. A. Frústulo en vista conectival. B-E. Valvas con cuatro, seis, ocho y diez procesos labiados respectivamente. F-G. Valvas externa e interna con cuatro procesos labiados. H. Vista interna de valva con seis procesos labiados. I-J. Vista externa e interna de valvas con cinco procesos labiados. K. Vista externa de aréolas dispuestas en líneas radiales y carentes de velum. Roseta central con aréolas angulares. Proceso labiado submarginal. L. Velum externo de las aréolas. M. Papilas sobre las paredes externas de las aréolas. Escalas: A, F-J $=20 \mu \mathrm{m} ; \mathrm{B}-\mathrm{E}=40 \mu \mathrm{m} ; \mathrm{K}=10 \mu \mathrm{m} ; \mathrm{L}=5 \mu \mathrm{m} ; \mathrm{M}=1 \mu \mathrm{m}$. 

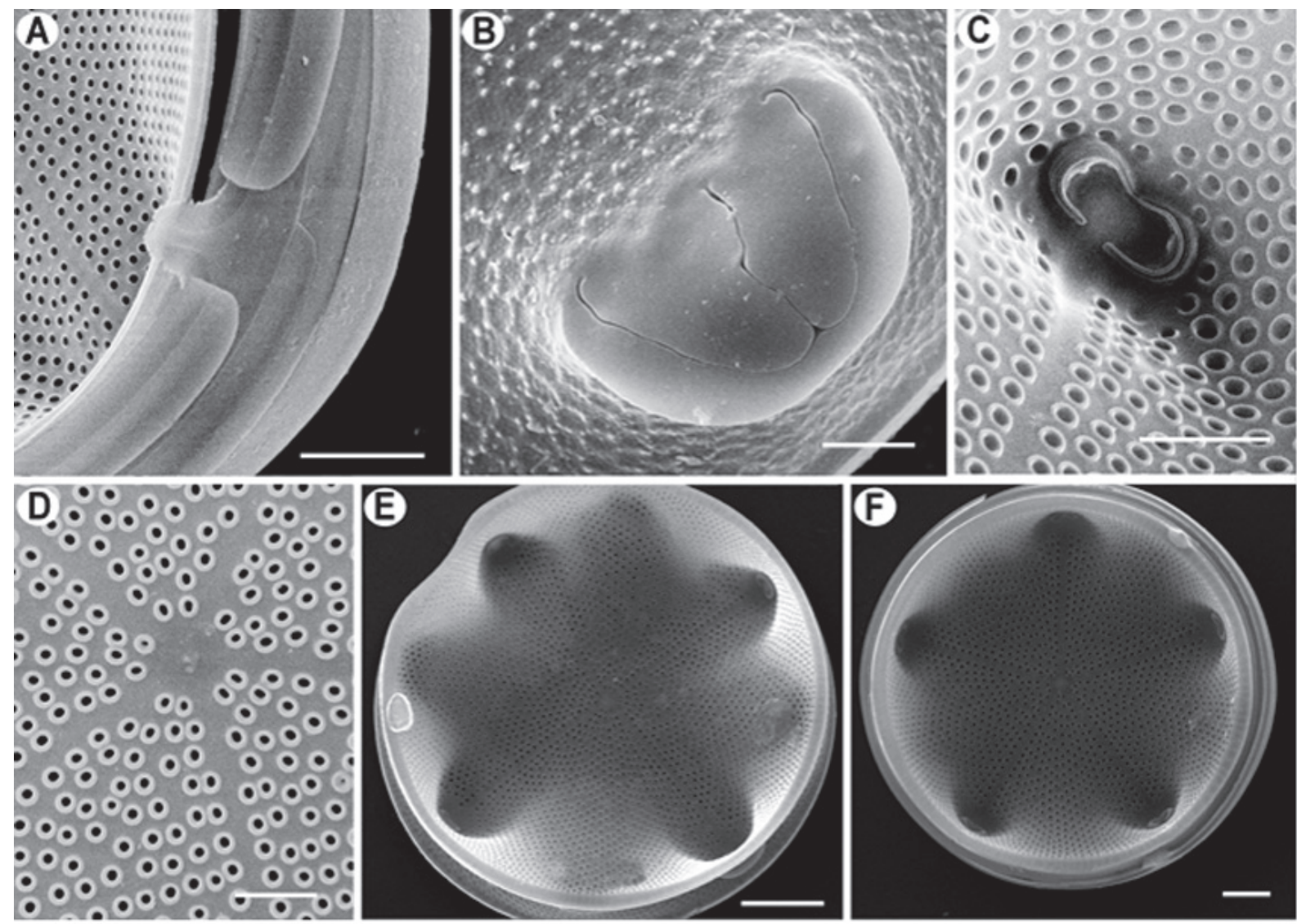

Figure 4. Aulacodiscus kittonii. A-F, Scanning Electron Microscopy. A. Cingulum with ligulate non perforated open bands. B. Three slits on the exterior surface of the labiate processes. C. Internal double horse-shoe-shaped labiate process. D. Internal foramina of areolae. E-F. Previously encircled valves observed with light microscopy having eight and ten labiate processes respectively show under scanning microscopy only four and five processes. Scale bars : A, $F=10 \mu \mathrm{m} ; \mathrm{B}-\mathrm{D}=5 \mu \mathrm{m} ; \mathrm{E}=20 \mu \mathrm{m}$.

Figura 4. Aulacodiscus kittonii. A-F, Microscopía Electrónica de Barrido. A. Cingulum con bandas liguladas no perforadas. B. Tres surcos sobre la cara exterior de cada proceso labiado. C. Parte interna del proceso labiado con forma de una doble herradura. D. Foramina interna de las aréolas. E-F. Valvas previamente marcadas en el microscopio fotónico provistas de ocho y diez procesos labiados respectivamente muestran en el microscopio de barrido solamente cuatro y cinco procesos. Escalas: A, $\mathrm{F}=10 \mu \mathrm{m}$; $\mathrm{B}-\mathrm{D}=5 \mu \mathrm{m} ; \mathrm{E}=20 \mu \mathrm{m}$.

\section{DISCUSSION}

Aulacodiscus kittonii belongs to the "kittonii" group of Aulacodiscus species, widely distributed in tropical and temperate waters and distinguished from other species of the genus by their external submarginal labiate processes expanded into large hyaline hood-like structures. According to Sims \& Holmes (1983) the group includes five taxa: $A$. kittonii Arnott in Pritchard 1861, described from recent marine material collected in New Zealand and Monterey Bay, California, and also fossil from this last locality; $A$. kittonii subsp. brightwellii (Janisch) Sims \& Holmes 1983, an extinct species described originally as A. brightwellii from Peruvian guano; A. johnsonii Arnott in Pritchard 1861, found as fossil in Algoa Bay guano, Africa; A. johnsonii var. amherstia (Venkateswarlu \& Round) Sims \& Holmes
1983, planktonic from Bay of Bengal India and described as Aulacodiscus amherstia, and A. africanus Cottam 1876, a recent and fossil species from the West coast of Africa.

A. kittonii differs from A. johnsonii and its variety amherstia by having three slits on the external part of each process which are not completely raised from the valve and by lacking a centrally raised papilla on the areolae. A. africanus is closely related to A. kittonii and mainly differs from it by having a single slit on the hood of processes. Differences between A. kittonii and A. kittonii subsp. brightwellii seem to be limited. While Wise (1951) considered Aulacodiscus brightwellii Janisch as a valid taxon (based mainly on the number of processes that ranges from five to nine and on the greater depth of the valves), Rattray (1888) and Hustedt (1930) considered it as a synonym of A. kittonii, and Sims \& Holmes (1983) as a subspecies. Considering that 
the remainder frustule features are similar in both species (morphology of areolae, processes, central rosette and morphometric values), we also agree to considerer it as a synonym of $A$. kittonii.

Aulacodiscus ehrenbergii described by Janisch 1861 from Peruvian guano is also a synonymous of $A$. kittonii. On the other hand, and in agreement with Holmes \& Mahood (1980), the description of "A. kittonii" by Ross \& Sims (1970) does not correspond to this species.

The morphological characteristics of the studied specimens of $A$. kittonii agree well with those described by Holmes \& Mahood (1980), Sims \& Holmes (1983) and Tiffany (2008). The number of labiate processes on each cell is a variable feature. With light microscopy, we observed normally valves with four, five, and six processes, and rarely, cells with eight or ten processes were also found (Fig. 3. D-E). As valves with those characteristics had not been found in our previous SEM observations of the same samples, clean material dried on cover glasses at room temperature was observed under a light microscope and valves with eight or ten processes were encircled with an special diamond objective. Their observation with scanning microscopy showed valves only with four (Fig. 4. E), or five processes (Fig. 4. F), proving that the "eight" and "ten" processes valves observed at low magnification with light microscopy were an optical effect produced by two un-separated valves, each one with four or five processes respectively. The same opinion was expressed by Holmes $\&$ Mahood (1980).

The small papillae on the external marginal walls of the areolae are also variable in number, but are present in all the individuals, and cells without papillae were not found in the Chilean material. They can be also observed in the valves studied by Sims \& Holmes (1983, Fig. 32) and Holmes \& Mahood (1980, Fig.19). Some variation was also found in the size of the areolae on the valve face. They are regularly 5 in $10 \mu \mathrm{m}$ on each striae at the central part, but those areolae, bordering the hyaline rays were wider and pentagonal in shape. This feature, and the fact that these areolae also have the internal foramina in an eccentric location, makes the hyaline rays very notorious when observed by light microscopy (Fig. 3. C-E).

This is the first record of Aulacodiscus kittonii as a recent and dominant "surf-diatom" species from the northern coast of Chile in the South Eastern Pacific Ocean. Accumulations of $A$. kittonii as the dominant species have until now only been reported from New Zealand, Brazil and the coast of Washington (Odebrecht et al. 2014).

Aulacodiscus kittonii is a littoral marine species with a wide distribution in both hemispheres: AFRICA: West coast of Africa; Algoa Bay guano; Madagascar (Sims \& Holmes 1983); Walvis Bay, South Africa (Burke \& Woodward 1963-1969). NORTH AMERICA: Washington; Oregon; Monterrey California (Arnott in Pritchard 1861, Holmes
\& Mahood 1980, Cupp 1943, Levin 1973), Pacific Coast (Boyer 1926-1927). CENTRAL AMERICA: VeraCruz, Mexico; Colon, Panama (Sims \& Holmes 1983); Maria Madre, Mexico (Burke \& Woodward 1963-1969). SOUTH AMERICA: Mejillones, Chile, fossil (Moeller 1891, Tempére \& Peragallo 1907, Frenguelli 1949); Pernambuco, Brasil (Rosevel et al. 2005 and Cabanez et al. 2010); Peruvian guano (Janisch 1861 as A. ehrenbergii and A. brightwellii.); Perú, neritic (Fernandez 1999). ASIA: Sendai, Japan (Sims \& Holmes 1983). AUSTRALASIA: New Zealand; Thursday Island (Arnott in Pritchard 1861, Foged 1979); Eocene of Connack's Rock, Oamaru, New Zealand (Tempére \& Peragallo 1889-1895). EUROPE incl. USSR: Golfe Juan, France; Moron, Spain; Baldjick, Bulgaria; Kamischer, USSR (Sims \& Holmes 1983); coast of Norway (Hendey 1964); Coast of England (Sims 1996).

According to the literature the beach of Coquimbo Bay presents several suitable conditions for the occurrence of "surf-diatom" accumulations: long sandy beach, near an active seaport, increased urbanization and human activities, strong winds and river discharge, among others (Lewin 1973, Campbell 1996, Odebrecht et al. 2014). On account to the above mentioned characteristics of the bay it could well be expected that new surf diatoms accumulations will repeat in the area in the future.

However, on September 16, 2015, a severe 8.4 Richter earthquake occurred in the Region of Coquimbo, Chile (covering the present studied area). The major earthquake triggered a tsunami event that destroyed several coastal localities in the Region and was particularly strong in Coquimbo Bay (La Serena City, Enjoy Beach), especially in the Coquimbo Port. This catastrophe could have drastic consequences on the ecosystems in the affected area, as was previously detected from some marine regions of Chile after the earthquake of 2010 (Fariña et al. 2012, Choi 2012). It is worth mentioning that the accumulations here described occurred when a new 2015 El Niño event was developing off Peru and northern Chile. Odebrecht et al. (2014) suggested that these events may, in the long term, lead to significant changes in "surf diatom" populations, as was found by Lange et al. (2000) in California coastal waters during El Niño 1997-98 conditions.

\section{ACKNOWLEDGMENTS}

The authors wish to express their grateful thanks to Dr. Clarisse Odebrecht and other anonymous reviewer for their helpful suggestions to the manuscript. We also thank to Dr. Luc Ector for his permanent support with the diatomist group of Concepcion, Chile. We thank the assistance of Mr. Pedro Arias T. for preparing the drawing of Coquimbo Bay. We also acknowledge the assistance of the staff of the Spectroscopy and Electron Microscopy Center, University 
of Concepción. Research Project partially subsidized by Directorship of Research, University of Concepción, Chile.

\section{REFERENCES}

ANDERSON, T.F. 1951. Techniques for the preservation of three dimensional structures in preparing specimens for the electron microscope. Annals of the New York Academy of Sciences, Ser. II, 13:130-134.

AnONYmous. 1975. Proposals for a standardization of diatom terminology and diagnosis. Nova Hedwigia Beiheft 53: 323-354.

Boyer, C.S. 1926-1927. Synopsis of North American Diatomaceae. Proceedings of the Academy of Natural Sciences of Philadelphia 78(1): 1-228 (1926), 79(2): 229-583 (1927).

Burke, J.F. \& J.B. Woodward. 1963-1969. A review of the Genus Aulacodiscus. Staten Island Institute of Arts \& Sciences, New York, 260 pp.

Cabanez, L., M. Silva-Cunha, M. Koening, F. Feitosa, M. Santiago \& K. Muniz. 2010. Variação temporal do fitoplâncton em três praias urbanas do litoral sul do estado de Pernambuco, Nordeste do Brasil. Acta Botanica Brasilica 24(1): 214224.

CAmpbell, E. 1996. The global distribution of surf diatom accumulations. Revista Chilena de Historia Natural 69: 495-501.

CHOI, C.Q. 2012. Chile Quake \& Tsunami Dramatically Altered Ecosystems. Livescience. URL; livescience.com/31404Chile-earthquake-ecosystem-impact.html.Viewed: September 28, 2015.

Cottam, A. 1876. On a new Aulacodiscus from the West coast of Africa. Journal of the Quekett Microscopical Club 4: 149153.

Cupp, E.E. 1943. Marine plankton Diatoms of the west coast of North America. Bulletin Scripps Institution of Oceanography 5(1): 1-238.

Dirección Meteorológica de Chile. 2016. Climatología. www. meteochile.gob.cl/climatología.php. Viewed: January 20, 2016.

Du Preez, D.R. \& E. Campbell. 1996. Cell coatings of surf diatoms. Revista Chilena de Historia Natural 69: 539-544.

Fariña, L.M., C. PASO \& P. Vera. 2012. Impactos ambientales del terremoto y tsunami en Chile. Las réplicas ocultas del 27F. Publicaciones Fundación Terram, Santiago, Chile. 161 pp.

Fernandez, A.M. 1999. Manual de las Diatomeas peruanas. Universidad Nacional de Trujillo. Publicaciones del Hortus Botanicus Truxillense, $276 \mathrm{pp}$.

Foged, N. 1979. Diatoms in New Zealand, the North Island. Bibliotheca Phycologica 47, 225 pp.

Frenguelli, J. 1949. Diatomeas fósiles de los yacimientos chilenos de Tiltil y Mejillones. Darwiniana 9(1): 97-157.

Hasle, G.R. \& G. Fryxell. 1970. Diatoms: cleaning and mouting for light and electron microscopy. Transactions of the American Microscopical Society 89: 469-474.

Hendey, N.I. 1964. An Introductory Account of the Smaller Algae of British Coastal waters. Part V: Bacillariophyceae (Diatoms). Her Majesty's Stationery Office, London. 317 pp.

Holmes, R.W. \& A. Maнood. 1980. Aulacodiscus kittonii Arnott
- Distribution and morphology on the West Coast of the United States. British Phycologycal Journal 15: 377-389.

Hustedt, F. 1930. Die Kieselalgen Deutschlands, Oesterreichs und der Schweiz. L. Rabenhorst's Kryptogamen-Flora von Deutschland, Oesterreich und der Schweiz 7(1): 609-920.

JANISCH, C. 1861. Zur Charakteristik des Guano's von verschiedenen Fundorten. Abhandlungen der Schlesischen Gesellschaft für vaterländische Kultur, Breslau. 150-164 S., Taf. 1-2.

Kaczmarska, I., L. Mather, I.A. Luddington, F. Muise \& J.M. EHRMAN. 2014. Cryptic diversity in a cosmopolitan known as Asterionellopsis glacialis (Fragillariaceae): Implications for ecology, biogeography, and taxonomy. American Journal of Botany 101(2): 267-286.

Lange, C., Weinheimer, A., Reid, F., Tappa, E. \& R. Thunel. 2000. Response of Siliceous Microplankton from the Santa Barbara Basin to the 1997-98 El Niño event. California Cooperative Oceanic Fisheries Investigations Reports 41: 186-193.

Lewin, J. 1973. Blooms of surf-zone diatoms along de Coast of the Olympic Peninsula, Washington. III. Changes in the Species Composition of the Blooms since 1925. Nova Hedwigia Beiheft 45: 251-257.

MölLER, J.D. 1891. Luchtdrucktafeln hervorragend schöener und vollständiger Möllerscher Diatomaceen-Präparate, 1891; Verzeichniss der in den Lichtdrucktafeln Möllerscher Diatomaceen-Präparate enthaltenen Arten. Wedel.

Odebrecht, C., D.R. Du Preez, P.C. Abreu \& E. Campbell. 2014. Surf zone diatoms: a review of the drivers, patterns and role in Sandy beaches fool chains. Estuarine, Coastal and Shelf Science 150 (A): 24-35.

Olivares, J. 1989. Aspectos hidrográficos de la Bahía de Coquimbo. Biología Pesquera 18: 97-108.

Pritchard, A. 1861. A History of Infusoria: including the Desmidiaceae and Diatomaceae, British and Foreign. 4th ed., Whittaker \& Co., London. 968 pp.

Rattray, J. 1888. A revision of the genus Aulacodiscus Ehr. Journal of Royal Microscopical Society 1888(3): 337-382.

Rosevel Da Silva, M., M. Silva-Cunha, F. Feitosa \& K. Muniz. 2005. Estructura da comunidade fitoplânctônica na Baía de Tamandaré (Pernambuco, Nordeste do Brasil). Tropical Oceanography, Recife 33(2): 163-181.

Ross, R. \& P.A. Sims. 1970. Studies of Aulacodiscus with the scanning electron microscope. Nova Hedwigia Beiheft 31: 49-88.

Ross, R., E. Cox, N.I. Karayeva, D.G. Mann, T.B.B. Paddock, R. SimONSEN \& P.A. Sims. 1979. An amended terminology for the siliceous components of diatom cell. Nova Hedwigia Beiheft 64: 513-533.

SIMS, P.A. 1996. An Atlas of British Diatoms. Biopress Ltd. 601 pp.

Sims, P.A. \& R.W. Holmes. 1983. Studies on the "kittonii" group of Aulacodiscus species. Bacillaria 6: 267-292.

Soto, M.V., M. Marker, C.P. Castro \& G. Rodolfi. 2015. Análisis integrado de las condiciones de amenaza natural en el medio ambiente costero semiárido de Chile. La Serena, Coquimbo. Boletín de la Asociación de Geógrafos Españoles 67: 213-231.

Tabilo, E., M. Sallaberry \& J.P. Myers. 1990. A shorebird banding program at Coquimbo Bay, Chile: some general observations and comments. Wader Study Group Bulletin, 60: $34-37$ 
TAlbot, M. \& G. Bate. 1990. A review of the ecology of surfzone diatoms, with special reference to Annaulus australis. Oceanographic Marine Biology Annual Review 28: 155175.

Tempère, J. \& H. Peragallo. 1889-1895. Diatomées Collection. Texte et Tables de la Collection des Diatomées du Monde Entier. Imp. Hy-Tribout, Paris, $304+62$ pp.

Tempère, J. \& H. Peragallo. 1907. Diatomées du Monde Entier. Edition 2, Fascicule 1, pp. 1-16. Arcachon, Grez-surLoing.
Tiffany, M.A. 2008. Valve development in Aulacodiscus. Diatom Research 23(1): 185-212.

Valle-Levison, A., J. Moraga, J. Olivares \& J.L. Blanco. 2000. Tidal and residual circulation in a semi-arid bay: Coquimbo Bay, Chile. Continental Shelf Research 20: 2009-2028.

Wise, F.C. 1951. Notes on some hitherto doubtful species of diatoms. Journal of the Quekett Microscopical Club 4(3): 285-293.

Recibido: 16.10 .15

Aceptado: 27.01.16 